\title{
Bioethics in Faith and Practice
}

December 2019

\section{Is Medical Education Ethical?}

Jonathan Handy

Indiana University

Dennis Sullivan

Cedarville University

Follow this and additional works at: https://digitalcommons.cedarville.edu/

bioethics_in_faith_and_practice

Part of the Bioethics and Medical Ethics Commons

DigitalCommons@Cedarville provides a publication platform for fully open access journals, which means that all articles are available on the Internet to all users immediately upon publication. However, the opinions and sentiments expressed by the authors of articles published in our journals do not necessarily indicate the endorsement or reflect the views of DigitalCommons@Cedarville, the Centennial Library, or Cedarville University and its employees. The authors are solely responsible for the content of their work. Please address questions to dc@cedarville.edu.

\section{Recommended Citation}

Handy, Jonathan and Sullivan, Dennis (2019) "Is Medical Education Ethical?," Bioethics in Faith and Practice: Vol. 4 : No. 1 , Article 2.

DOI: 10.15385/jbfp.2019.4.1.2

Available at: https://digitalcommons.cedarville.edu/bioethics_in_faith_and_practice/vol4/iss1/2 


\title{
Is Medical Education Ethical?
}

\author{
Abstract \\ No abstract provided \\ Keywords \\ medical education, medical training, beneficence \\ Creative Commons License \\ (c) (i) (9)
}

This work is licensed under a Creative Commons Attribution-Noncommercial-No Derivative Works 4.0 License. 


\section{Is Medical Education Ethical?}

\section{Jon R. Handy, Medical Student, Indiana University School of Medicine Dennis M. Sullivan, MD, MA (Ethics), Cedarville University}

Every medical student eventually faces a significant personal dilemma. This is rooted in the very nature of medical education, yet seems contrary to the oath we will take when we enter the profession. It is that face-to-face moment with a patient, when we are about to do a procedure for the first time and we realize we are not qualified for it. We look over to the doctor teaching us, hoping that neither he nor the patient see the fear in our eyes over our lack of skill.

That moment came for me early in my medical training, when I was working at a local clinic. The middle-aged woman in front of me seemed perfectly healthy, except for some dental issues that were not our current concern. When we asked her what had brought her in that day, she explained that she had suffered from untreated breast cancer for seven years. After a thorough history, we began the physical exam. This early in my education, I immediately worried about respecting the patient's modesty and comfort, but she assured me there was no problem.

Our exam revealed infected breast tissue surrounding the tumor masses that had developed in her chest. To help me better understand the extent of the disease, my preceptor had me palpate the woman's breast and feel the difference between healthy tissue and the cancer, including severely affected areas that were necrotic and painful. The whole time I wondered if it was even my place to examine her. Despite her earlier assurances, I felt that I was infringing upon an area of medicine I was not yet fit to be a part of. I feared hurting her by palpating too hard, though my instructor insisted I fully examine her. I began to question the extra discomfort patients go through for medical students' educational benefit. I also wonder if the extra time it takes to teach students prolongs the situation for patients. All of these things seemed to be a hindrance patient care, purely for learning experience.

There is no question that teaching medical students how to be doctors is necessary for the future of medicine and for the population as a whole. But we also know that our skills and knowledge are less than adequate at present. When we stood before our mentors, families, and peers to swear a modern version of the Hippocratic Oath, we vowed to do our best for our patients. In other words, we affirmed the age-old principle of beneficence. So does the whole enterprise of training unskilled medical students contradict this principle?

Four hundred years before the time of Christ, an ancient guild of medical practitioners embarked upon their training by swearing an oath to a pagan pantheon of gods, among them Apollo the healer and his son Asclepius, along with Hygieia and Panacea and other deities. The original oath contained specific promises to use treatment to help the sick, but never to harm them. ${ }^{1}$ Over two millennia later, these ideas have been formalized as beneficence and non-maleficence, two of the four main concepts (along with autonomy and distributive justice) of medical principlism, the foundation of modern medical ethics. ${ }^{2}$

Non-maleficence is the most basic and foundational principle in bioethics that states "at the very least, don't hurt the patient." This differs from beneficence, which calls us to a much higher standard of care. Beneficence demands that we not only prevent harm, but that we should leave our patients better than we found them. Though some recent authors have pointed out that these ideas have been diluted in our modern context, ${ }^{3}$ the principles demand much more of us than first meets the eye.

Bioethics in Faith and Practice vol. 4 no. 1, pp. 5-7. ISSN 2374-1597 (C 2019, Jonathan Handy and Dennis Sullivan, licensed under CC BY-NC-ND (http://creativecommons.org/licenses/bync-nd/4.0/ ) 
Beneficence is an active process, not just a passive one. This means that we are called to advocate for our patients, and to actively seek opportunities to provide better care for them. This goes above and beyond making the best treatment decision when the opportunity arises. Beyond choosing treatment $\mathrm{A}$ or treatment $\mathrm{B}$, beneficence demands that we look outside of the current situation and provide exemplary care. This may mean checking on our patients more often, and caring for needs not bounded merely by test results and patient outcome measures. This may entail sacrificing our own time and needs to go beyond the dictates of mere duty.

In the language of moral philosophy, most of our actions are morally neutral, such as what shirt we should wear on a given day, or what route to take on our way to work. Some acts are morally obligatory, and always required. In a medical context, this might include performing CPR for a patient in cardiac arrest, or urgently providing medication to a patient in overwhelming pain. There is, however, a third type of act, one that is supererogatory, or heroic. This entails going the extra mile, going above and beyond the dictates of mere duty. ${ }^{4}$

In this way of looking at it, non-maleficence corresponds with simple obligation, whereas beneficence is supererogatory. If so, then the medical profession is largely a heroic enterprise. It is active, not passive; it is sacrificial, not ordinary. Whereas for most people, a heroic act is a free choice, for doctors, it becomes a professional obligation by virtue of the Oath. In this light, physicians no longer have a choice in the matter; they must always be heroes.

Once we recognize the obligatory nature of supererogatory beneficence in medicine, we can understand its relationship with medical education. Beneficence is arguably the most important part of medical principlism, necessitating adherence to the other three core principles. To do the most good for our patients, we must respect their autonomy and allow them to be a part of the decision-making process. We must also allocate resources justly to do the most good for the most patients. Most notably, to do this kind of good we must avoid harming our patients. Herein lie the unique opportunities for beneficence in medical education.

Medical students face a paradox: they must be beneficent toward patients while having only a few of the skills to do so. But in the paradox, we have the freedom to do what is best for them. While it may be true that we have fewer skills, this necessarily means that we take care of fewer patients, giving us more time to learn. We can capitalize on this opportunity and provide individualized and focused care to each assigned patient. An attending physician is constrained by a large patient load, while we can focus on our patients one-on-one. This will give us a greater understanding of each one's symptoms, history, and fears.

Medical students have the unique chance to provide a holistic approach to patient care, filling in gaps that busy attending physicians don't have time for. For each patient, we can set their minds at ease and provide them with personalized attention and to make them feel more comfortable navigating an uncertain and often frightening time in their lives. The extra time afforded to medical students is also an opportunity to learn the disease state and master its pathophysiology and treatment. This benefits patients, because they have a medical advocate intensely studying their case and ensuring that the treatment is up to the current standard of care or better. These seems like a covenantal relationship, very compatible with the Hippocratic tradition.

Yet we can take this case even further. If medical education can be beneficent toward our current patients, then it will also benefit our future patients. The obvious yet important value of the medical education system is the first-hand knowledge and understanding of unique cases that will equip us to treat future patients. During these formative years of our career, we can appreciate the details of each case.

Comparing one with another will give us a comprehensive view of medicine and how diseases are related. All of these experiences will prepare us to provide personalized and evidence-based care to our future 
patients. So there are two big reasons this all works out well: our patients benefit from our hard work, but they can also be encouraged, knowing that they help us to learn as well. The more intently we focus on giving the best care we currently can, the firmer our foundation will become for our later career.

As medical students, we all fear that we might do more harm than good. My initial encounter with a patient with far-advanced breast cancer is a good example of the doubts I experienced at that early stage of training. Yet I'll never forget my emotions as I completed that early, hesitating breast exam, as the patient thanked me for taking the time to examine her.

Should we continue our journey through the medical education system with the mantra "the ends justify the means," while feeling vaguely guilty about the process the whole time? It does not need to be this way. We should approach medicine with beneficence firmly in mind, recognizing that we are joining a noble, demanding, and heroic profession. Only then can we minimize the risks to our patients, while providing better care than would be possible without us.

\section{Endnotes:}

${ }^{1}$ Cameron N. The New Medicine: Life and Death after Hippocrates. Chicago: Bioethics Press; 2001.

${ }^{2}$ Beauchamp TL, Childress JF. Principles of biomedical ethics. 7th ed. New York: Oxford University Press; 2013.

${ }^{3}$ Smith L. A brief history of medicine's Hippocratic Oath, or how times have changed. Otolaryngology-Head And Neck Surgery: Official Journal Of American Academy Of Otolaryngology-Head And Neck Surgery. 2008;139(1):1-4.

${ }^{4}$ Feinberg JS, Feinberg PD. Ethics for a brave new world. 2nd ed. Wheaton, Ill.: Crossway; 2010. 